\title{
Evidence for the Presence of Protein Kinases Which Stimulate Phosphorylation of $c$-erb A Protein in Rat Kidney Nuclei
}

\author{
Kiyoshi HASHIZUME, KaZUO ICHIKAWA, SATORU SUZUKI, \\ Teiji TAKEDA, Keishi YAMAUCHI, And Mutsuhiro KOBAYASHI \\ Department of Geriatrics, Endocrinology and Metabolism, \\ Shinshu University School of Medicine, Matsumoto 390, Japan
}

\begin{abstract}
Protein kinases were separated from rat kidney nuclear extract by hydroxylapatite column chromatography. Five (I-V) different protein kinases were isolated when histone was used as a substrate. Two (I and III) of them stimulated phosphorylation of $c$-erb $A-\beta$ protein $(50 \mathrm{kDa}$ ) expressed in Escherichia coli. The $c$-erb $A$ product has an activity of high affinity $\mathrm{T}_{3}$ binding. One (I) of the kinases was dependent on cyclic adenosine 3', 5'-monophosphate (cyclic AMP). The other kinase (III) was not dependent on cyclic nucleotides. The latter kinase was eluted from hydroxylapatite column with $0.05 \mathrm{M} \mathrm{PO}_{4}$ at $\mathrm{pH}$ 7.4. The sedimentation coefficient(s) estimated by continuous sucrose density gradient centrifugation was approximately 6.0. Km values for ATP were estimated by double reciprocal analyses, which gave 110.0 $\mu \mathrm{M}$ in the protein kinase I (in the presence of $10^{-6} \mathrm{M}$ cyclic AMP) and $25 \mu \mathrm{M}$ in the protein kinase III, respectively. The data showed that $1.0 \mathrm{~mol}$ phosphate was incorporated into $80 \mathrm{~mol}$ of $c$-erb A protein (50 $\mathrm{kDa}$ ) either in the presence of protein kinase I (with $10^{-6} \mathrm{M}$ cyclic AMP) or in the presence of protein kinase III. These results suggested that there are protein kinases for $c$-erb $A$ protein, whose functional properties are similar to those of nuclear $\mathrm{T}_{3}$ receptor, in rat kidney nuclei.
\end{abstract}

(Endocrinol Japon 38: 205-212, 1991)

IT IS WELL documented that mammalian genomes contain multiple $c$-erb $A-\beta$ related genes $[1,2]$. Some of them encode high affinity $\mathrm{T}_{3}$ receptors $[2-5] . \mathrm{T}_{3}$ receptors mediate hormone action by modulating the transcription of specific genes. This process requires receptors to bind to regulatory DNA sequence elements located close to the target genes [6-9]. It has also been demonstrated that steroid hormone receptors which have functional properties similar to those of thyroid hormone receptors $[10,11]$ could be phosphorylated, although the role of the phosphorylation events has not been thoroughly clarified [12, 13]. Recently, it has been reported that c-erb $A$ product was also phosphorylated under stimulation of cyclic adenosine 3', 5'-monophosphate (cyclic AMP)-dependent protein kinase or of protein

Received: January 8, 1991

Accepted: March 15, 1991

Correspondence to: Dr. Kiyoshi HASHIZUME, Department of Geriatrics, Endocrinology and Metabolism, Shinshu University School of Medicine, 3-1-1 Asahi, Matsumoto 390, Japan. kinase C [14]. However, it is not certain whether thyroid hormone receptors are phosphorylated through the activation of protein kinase present in the nucleus or not. In this study, we aimed to identify the kinase(s) which phosphorylates $c$-erb $A$ protein in rat kidney nuclei.

\section{Materials and Methods}

\section{Materials}

DNA restriction, ligation, and electrophoresis were performed as described by Maniatis et al. [15]. 3,5,3'-Triiodo-L-thyronine ( $\mathrm{L}-\mathrm{T}_{3}$ ), adenosine 3', 5'-monophosphate (cyclic AMP), adenosine 5'-triphosphate, isobutylmethyl-xanthine, histone, casein, and bovine serum albumin (BSA) (Fraction V) were obtained from Sigma Chemical Co. (St. Louis, MO). Phenylmethylsulfonyl fluoride (PMSF), sodium dodecyl sulfate (SDS) and dithiothreitol (DTT) were from Nakarai Chemical Co. (Kyoto, Japan). Isopropyl-B-D-thiogalacto- 
pyranoside was purchased from Wako Chemical Co. (Osaka, Japan). E coli-expression plasmid pKK233-2, double stranded calf thymus DNAcellulose, Sephacryl S-200, Sephacryl S-300, mono Q-Sepharose and protein A were from Pharmacia Fine Chemicals Inc. (Piskataway, NJ). Restriction enzymes were from Takara Shuzou Co. (Tokyo, Japan). Extracti-gel D and reagents for SDSpolyacrylamide gel electrophoresis (SDS-PAGE), Dowex 1-X8, $\mathrm{Cl}^{-}$, 200-400 mesh, anion exchange resin were obtained from Bio-Rad (Richmond, CA). X-ray film (XAR-5) and developing solutions were from Eastman Kodak (Rochester NY). Intensifying screens were from Fuji Film (Tokyo, Japan). $\left[{ }^{125} \mathrm{I}\right]$ Triiodo-L-thyronine $\left(\left[{ }^{125} \mathrm{I}\right] \mathrm{T}_{3}\right)(3000$ $\mu \mathrm{Ci} / \mu \mathrm{g})$ and $\gamma-\left[{ }^{32} \mathrm{P}\right]$ adenosine 5 '-triphosphate $(\gamma$ $\left[{ }^{32} \mathrm{P}\right] \mathrm{ATP}(100-\mu \mathrm{Ci} / \mathrm{nmol})$ were purchased from New England Nuclear (Boston, MA).

Construction of plasmid and Preparation of c-erb A protein

Construction of plasmid, pNTR which expresses human $c$-erb $A$ protein in $E$. coli, and the preparation of $c$-erb $A$ protein was performed as previously described [5] . In this plasmid, the entire coding region of human c-erb $A$ [2] is located in the blunt-ended NcoI site of pKK233-2. This construction located the first methionine codon of the translated region of $c$-erb $A$ cDNA at 13 bases downstream of the lac $Z$ ribosome binding sequence (AGGA) of pKK233-2 and produced a non-fusion $c$-erb $A$ protein. Additionally, in order to increase the yield of the protein, the DNA sequence containing the c-erb $A$ DNA and promoter region was transferred to a $p U C$ plasmid, which has an extremely high copy number in E. coli. After propagation of E. coli (JM103) that were transformed with pNTR, the expression of $c$-erb $A$ was induced by isopropyl-B-D-thiogalactopyranoside without glucose. After $14 \mathrm{~h}$ incubation, E. coli collected by centrifugation was solubilized by sonication and freezing.

\section{Preparation of anti-c-erb $A$ antibody}

$c$-erb $A$ expressed in $E$. coli was partially purified by sequential fractionation with hydroxylapatite, mono Q-Sepharose and Sephacryl S-200 or S-300 column chromatography and was localized in SDS-PAGE [5, 16]. A protein band of synthesized $c$-erb $A$ product ( $50 \mathrm{kDa}$ ) was excised from the gel and was eluted from the gel by electrophoresis.
The final product was immunized to rabbit. The antibody ( $\gamma$-globulin fraction) was partially purified by DEAE-cellulose column chromatography and by precipitation with ammonium sulfate.

Preparation of protein kinases from rat kidney nuclei Nuclear fraction was prepared from $150 \mathrm{~g}$ male Wistar rats (10 animals) as previously described using discontinuous sucrose density gradient centrifugation $[17,18]$. The isolated nuclei showed a protein/DNA ratio of 2.7 and DNA recovery of 60-70\%. Phase contrast microscopic observations revealed intact nuclei with minimal cytoplasmic contamination. The nuclei were washed with 10

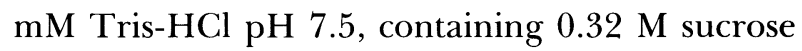
and $5.0 \mathrm{mM} \mathrm{MgCl}_{2}$ three times in order to remove extranuclear components. The extract which was prepared by incubation of the nuclei with $10 \mathrm{mM}$ potassium phosphate buffer $\mathrm{pH} 7.4$, containing $0.4 \mathrm{M} \mathrm{KCl}, 5.0 \mathrm{mM} \mathrm{MgCl}_{2}$ (KMP) was applied to a column $(1.0 \times 10.0 \mathrm{~cm})$ of hydroxylapatite. After washing the gel thoroughly with KMP, proteins were eluted with a $200 \mathrm{~m} l$ linear gradient of sodium phosphate buffer $\mathrm{pH} 7.4$ from 10.0 to $100.0 \mathrm{mM}$.

Estimation of molecular weight (s value) of protein kinase

Each protein kinase activity separated by hydroxylapatite column chromatography was applied to a continuous sucrose density gradient (5-20\%). The gradient was prepared in $10.0 \mathrm{mM}$ sodium phosphate buffer $\mathrm{pH} 7.4$, containing 0.2 $\mathrm{M} \mathrm{NaCl}, 3.0 \mathrm{mM} \mathrm{MgCl} 2,0.5 \mathrm{mM}$ DTT, and 0.5 $\mathrm{mM}$ EGTA. After applying each protein kinase $(100 \mu l)$ onto the top of the gradient, the tubes $(4.8 \mathrm{~m} l$ each) were centrifuged at $50,000 \mathrm{rpm}$ for $12 \mathrm{~h}$ at $2^{\circ} \mathrm{C}$ in an sw 60 rotor (Beckman Ultracentrifuge). External molecular weight markers were simultaneously sedimented as the standard for the evaluation of the sedimentation coefficient as previously described $[17,18]$.

\section{$\left.{ }^{125} I\right] T_{3}$ binding assay}

Assay of binding of $\left[{ }^{125} \mathrm{I} \mathrm{T}_{3}\right.$ to the $c$-erb $A$ protein was performed as previously described [19]. Dowex anion-exchange resin was used for the separation of bound $\left[{ }^{125} \mathrm{I}\right] \mathrm{T}_{3}$ from free $\left[{ }^{125} \mathrm{I}\right] \mathrm{T}_{3}$ [20]. The specific binding was defined as total $\left.{ }^{125} \mathrm{I}\right] \mathrm{T}_{3}$ binding (in the absence of unlabeled $\mathrm{T}_{3}$ ) minus the amount of $\left[{ }^{125} \mathrm{I}\right] \mathrm{T}_{3}$ bound in the 
presence of $10^{-6} \mathrm{M}$ unlabeled $\mathrm{T}_{3}$.

\section{Protein kinase assay}

Protein kinase activities isolated from rat kidney nuclei were measured by the method as previously described [21]. Histone (5 $\mu \mathrm{g} /$ tube) or casein (15 $\mu \mathrm{g} /$ tube) were used as the substrate for the kinases. The enzyme fraction $(100 \mu l)$ was incubated with radioactive ATP $\left(1.5 \times 10^{4} \mathrm{cpm}\right.$ added $)$ in a final volume of $150 \mu \mathrm{l}$ of incubation medium $(20 \mathrm{mM}$ Tris- $\mathrm{HCl}$, $\mathrm{pH} 7.4$, containing $3.0 \mathrm{mM} \mathrm{MgCl}_{2}, 0.5$ mM DTT, $0.5 \mathrm{mM}$ EGTA and $10.0 \mathrm{mM} \mathrm{NaF}$ (TMDE) for $5 \mathrm{~min}$ at $22^{\circ} \mathrm{C}$. The final concentration of ATP (including radioactive ATP) was adjusted to $10^{-5} \mathrm{M}$ by adding unlabeled ATP. In several experiments, $10^{-6} \mathrm{M}$ cyclic AMP and 1.0 $\mathrm{mM}$ isobutylmethyl xanthine were added. The reaction was terminated by adding $10.0 \%$ trichloroacetic acid (TCA) $(37.5 \mu l)$. After addition of $50 \mu l$ of $0.63 \%$ BSA, the mixture was vortexed for a short time (approximately $2.0 \mathrm{sec}$ ) and TCA-insoluble material was precipitated by centrifugation. The precipitate was washed with $2.5 \%$ TCA twice and the final precipitate was dissolved with $50 \mu l$ of $90.0 \%$ formic acid, then the dissolved material was transferred to a counting vial which contained scintillation liquid $(4.0 \mathrm{ml})$, and radioactivity was measured by Liquid Scintillation Spectrometer (Packard Instrument Co., Downers Grove, IL).

Phosphorylation of c-erb A protein, SDS-polyacrylamide gel electrophoresis and autoradiography

c-erb $A$ protein-containing fraction (E. coli extract) (100-200 $\mu \mathrm{g}$ protein) was incubated with an appropriate amount of protein kinase (s) in the presence of $\gamma-\left[{ }^{32} \mathrm{P}\right] \mathrm{ATP}(1.0 \mu \mathrm{Ci})$ for $5 \mathrm{~min}$ at $22^{\circ} \mathrm{C}$ in a final volume of $150 \mu l$ TMDE. The final concentration of ATP (including radioactive ATP) was adjusted to $10^{-5} \mathrm{M}$ by adding unlabeled ATP. The reaction was terminated by boiling the mixture for $5 \mathrm{~min}$ after the addition of Laemmli's sample buffer with $100 \mathrm{mM}$ DTT. Electrophoresis of the phosphorylated proteins was performed in the presence of $0.1 \%$ SDS by the method of Laemmli [22]. The samples were separated on a $1.5 \mathrm{~mm}$ thick $10 \%$ polyacrylamide slab gel. Gels were stained with Coomasie Brilliant R-250 Blue, destained, dried and exposed to X-ray films at $-70^{\circ} \mathrm{C}$. The amount of $\left[{ }^{32} \mathrm{P}\right]$ incorporated into proteins was quantitated by the method employing the Cerenkov effect of the protein band excised.

\section{Immunoprecipitation of c-erb $A$ protein}

The phosphorylated samples were incubated with Laemmli's sample buffer ( $50 \mu l$ ) for $30 \mathrm{~min}$ at room temperature. After the incubation, each sample was passed through a column $(0.5 \times 0.5$ $\mathrm{cm})$ of Extracti-gel D to remove SDS. The eluted material was incubated with $50 \mu l$ of anti c-erb $\mathrm{A}$ antibody (diluted to $1: 10,000$ ) for $12 \mathrm{~h}$ at $10^{\circ} \mathrm{C}$. After the incubation, the immune-complexes were separated using protein A adsorption. The complexes were boiled after the addition of Laemmli's sample buffer with $100 \mathrm{mM}$ DTT and were applied to an SDS-PAGE. Radioactive phosphoproteins developed on the gel were analyzed by autoradiography.

\section{Protein concentration measurement}

Protein concentration was measured by the method of Lowry et al. [23] with BSA as the standard. The protein concentration of c-erb A band developed on the SDS-PAGE gel was estimated with a densitometer (Hitachi, Tokyo, Japan).

\section{Results}

Characteristics of $\left[{ }^{125} I\right] T_{3}$ binding to the c-erb A protein expressed in Escherichia Coli

As previously described, the $50 \mathrm{kDa}$ product of c-erb $A$ bound $\mathrm{T}_{3}$ with an affinity constant of $4.3 \pm 0.6 \times 10^{9} \mathrm{M}^{-1}$ (mean $\pm \mathrm{SD}$ for 5 experiments). The order of affinity for iodothyronine analogues was triiodothyroacetic acid > 3,5,3'-triiodo-Lthyronine $>3,5,3$ '-triiodo-D-thyronine $>\mathrm{L}$ thyroxine, and $\left[{ }^{125} \mathrm{I}\right] \mathrm{T}_{3}$-c-erb $A$ protein complex bound to DNA cellulose [5].

\section{Isolation of protein kinases from rat kidney}

By hydroxylapatite column chromatography of rat kidney nuclear extract, 5 different protein kinase activities (I-V) were separated when histone (whole histone) was used as a substrate (Fig. 1). When casein was used as a substrate, protein kinases I and II were detected (data not shown). The activity of protein kinase I was dependent on cyclic AMP. $\left[{ }^{125} \mathrm{I}\right] \mathrm{T}_{3}$ binding activity (nuclear $\mathrm{T}_{3}$ receptor) was eluted with $0.22-0.28 \mathrm{M}$ sodium 


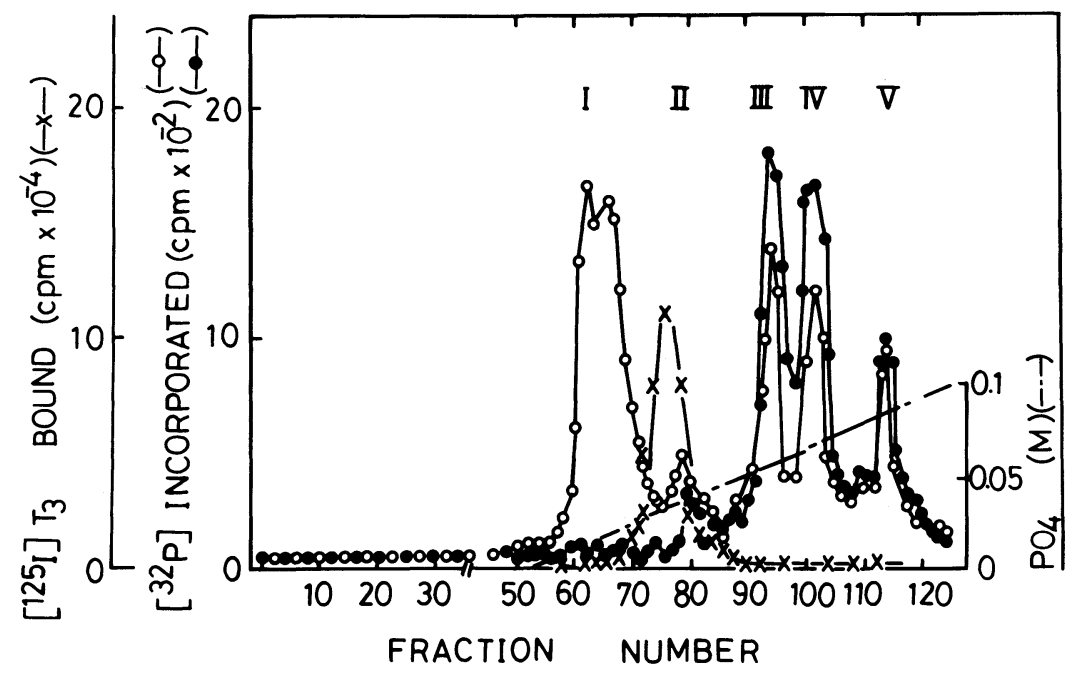

Fig. 1. Isolation of protein kinases from rat kidney nuclei. Nuclear extract obtained from rat kidney was applied to a column of hydroxylapatite, and proteins were eluted with $200 \mathrm{ml}$ of linear gradient of sodium phosphate buffer (pH 7.4) as described under "Materials and Methods". Protein kinase activity was measured using Histone as a substrate in the absence $(0)$ or presence $(\bigcirc)$ of $10^{-6} \mathrm{M}$ cyclic AMP. $\left[{ }^{125} \mathrm{I}^{-} \mathrm{T}_{3}\right.$ binding activity was also measured in each fraction $(\mathrm{x})$, in which $\left.{ }^{125} \mathrm{I}\right] \mathrm{T}_{3}(150,000 \mathrm{cpm}$ added) was incubated with $100 \mu \mathrm{l}$ aliquots in the presence of $0.5 \mathrm{mM}$ DTT For $4 \mathrm{~h}$ at room temperature. Specific binding is illustrated.

phosphate. The elution position of the receptor was between those of protein kinases I and II.

\section{Phosphorylation of c-erb $A$ protein}

$c$-erb $A$ protein $(50 \mathrm{kDa})$ was phosphorylated in the presence of protein kinase I or III. As is shown in Fig. 2, the potency of the enzyme activity was higher in protein kinase III than in protein kinase I. The stimulation of phosphorylation by protein kinase I was only observed in the presence of cyclic AMP. However, kinase III was not dependent on cyclic AMP or cyclic GMP (data not shown). Phosphorylation of this $50 \mathrm{kDa}$ protein was not observed when whole $E$. coli (c-erb $A$ was not expressed) extract was incubated with protein kinase III or kinase I in the presence of cyclic AMP. The phosphorylation of $c$-erb $A$ protein by kinase III was observed in its concentration dependent fashion (Fig. 3, lane C to $\mathrm{H}$ ). The phosphorylated c-erb $A$ protein which was generated by incubation with a minimal concentration of protein kinase III ( $1.25 \mu \mathrm{g}$ protein) was concentrated by immunoprecipitation with anti c-erb $A$ antibody (Fig. 4). Phosphorylated protein band which corresponded to the $c$-erb $A$ protein was not observed when whole $E$. coli (c-erb $A$ was not expressed) extract was incubated with the kinase (Fig. 3, lanes
A and B). Fifty-five kDa protein which was one of the components of E. coli was also phosphorylated in the presence of kinase III in proportion to the concentration of the enzyme. However, the phosphorylation of $55 \mathrm{kDa}$ protein was very low in the absence of $c$-erb $A$ protein even though incubation was performed with a maximal concentration (15.0 $\mu \mathrm{g}$ protein) of kinase III. When protein kinase III alone was incubated under the same condition as the phosphorylation reaction, no phosphorylated protein band was observed (data not shown). A study with sucrose density gradient centrifugation of protein kinase III showed that the kinase was $6.0 \mathrm{~s}$ of sedimentation coefficient (Fig. 5). In this study, a large amount of protein kinase activity was sedimented to the bottom of the tube, suggesting that protein-protein interaction among proteins might have occurred. As shown in Fig. 5, phosphorylated material (Band X) which was one of the components of $E$. coli was also phosphorylated. The $s$ value for maximal phosphorylation, however, was different from that of protein kinase III, indicating that the fraction which contained protein kinase III contained kinase(s) distinct from protein kinase III.

Protein kinase I was also applied to sucrose density gradient centrifugation. The kinase activ- 


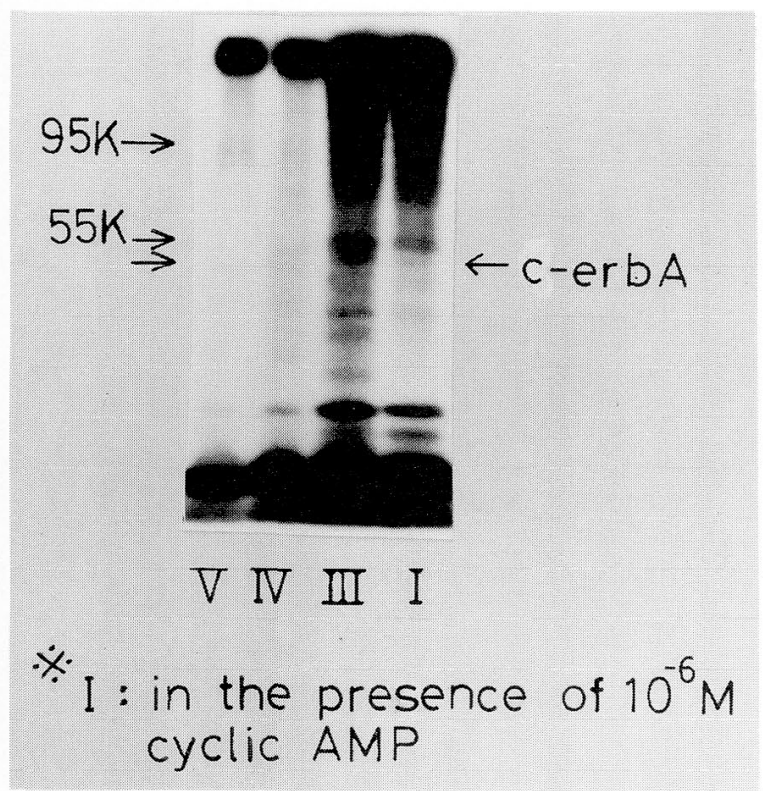

Fig. 2. Phosphorylation of $c$-erb A protein. Protein kinases I, III, IV and V were obtained as shown in Fig. 1. c-erb A protein-containing fraction $(200 \mu \mathrm{g}$ protein) which was obtained by solubilization of $E$. coli that expressed c-erb $A$ was incubated with $\mathrm{r}\left[{ }^{32} \mathrm{P}\right] \mathrm{ATP}$ in the presence of $25 \mu \mathrm{g}$ protein of protcin kinase I, III, IV or V. After the reaction, phosphorylated proteins were analyzed by autoradiography of the proteins separated on SDSPAGE. Phosphorylation reaction was performed in the presence of $10^{-6} \mathrm{M}$ cyclic AMP in the case of stimulation with protein kinase I. Similar results were obtained with 2 different lines of solubilized fraction prepared from E. coli which expressed c-erb A.

ity was separated into two activities. One was $7.2-6.8 s$ and the other was 3.6-2.5s of the sedimentation coefficient. The $K m$ values for ATP were estimated by double reciprocal analyses. As is shown in Fig. 6, the $K m$ was $25 \mu \mathrm{M}$ in protcin kinase III, whereas the value was $110 \mu \mathrm{M}$ in protein kinase $\mathrm{I}$ in the presence of $10^{-6} \mathrm{M}$ cyclic AMP. The $K m$ value was not influenced by the addition of 0.1-1.0 $\mathrm{mM} \mathrm{Ca}^{2+}$ and $10 \mu \mathrm{M}$ phosphatidylserine. A study with double reciprocal analysis showed that $0.25 \mathrm{pmol}$ phosphate was incorporated into $20 \mathrm{pmol} c$-erb $A$ protein $(1 \mathrm{~mol}$ phosphate $/ 80 \mathrm{~mol} c$-erb $A$ protein) in the presence of protein kinase I (in the presence of $10^{-6} \mathrm{M}$ cyclic AMP) or in the presence of protein kinase III.

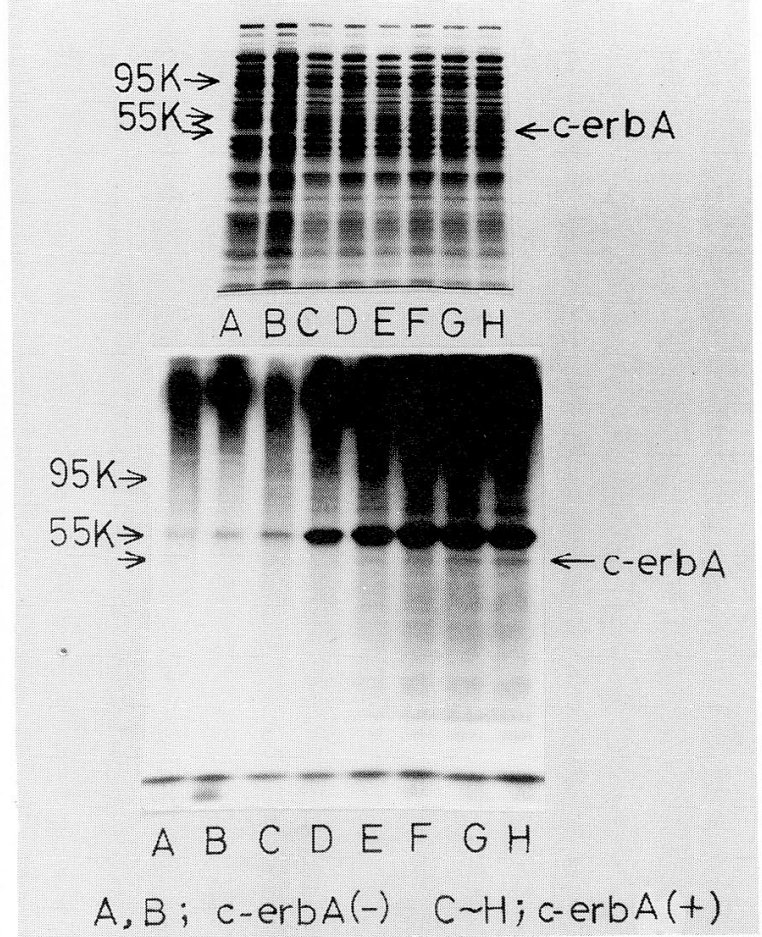

Fig. 3. Effect of various concentrations of protein kinase III on the phosphorylation of c-erb A protein. c-erb A protein-containing $E$. coli extract (200 $\mu$ g protein) (lanes C-H) or extract of control E. coli which did not express c-erb $A$ (lanes A and B) was incubated in the absence (lanes A and C) or presence of $1.25 \mu \mathrm{g}(\mathrm{D}), 2.5$ $\mu \mathrm{g}(\mathrm{E}), 5.0 \mu \mathrm{g}(\mathrm{F}), 10.0 \mu \mathrm{g}(\mathrm{G})$ or $15.0 \mu \mathrm{g}(\mathrm{H})$ of protein kinase III with $\mathrm{r}\left[{ }^{32} \mathrm{P}\right] \mathrm{ATP}$ and unlabeled ATP as described under "Materials and Methods". After incubation the materials were applied to SDS-PAGE. The upper panel shows the protein bands stained with Coomasie Brilliant R-250 Blue, and lower panel shows autoradiography of the phosphorylated proteins.

\section{Discussion}

We previously demonstrated that cyclic AMPdependent protein kinase prepared from rat liver stimulated the phosphorylation of $c$-erb $A-\beta$ protein in vitro [24]. Goldberg and his coworkers demonstrated that the phosphorylation of $c$-erb $A$ product was enhanced 10 -fold by treatment of the avian erythroblastosis virus-transformed cells with activators of either protein kinase $\mathrm{C}$ or cyclic AMP-dependent protein kinase [14]. We observed that cyclic AMP-dependent protein kinase, which was present in rat kidney nuclei, phosphorylated the c-erb A protein. Thus, the cyclic AMPdependent kinases, both extra- and intranuclear 


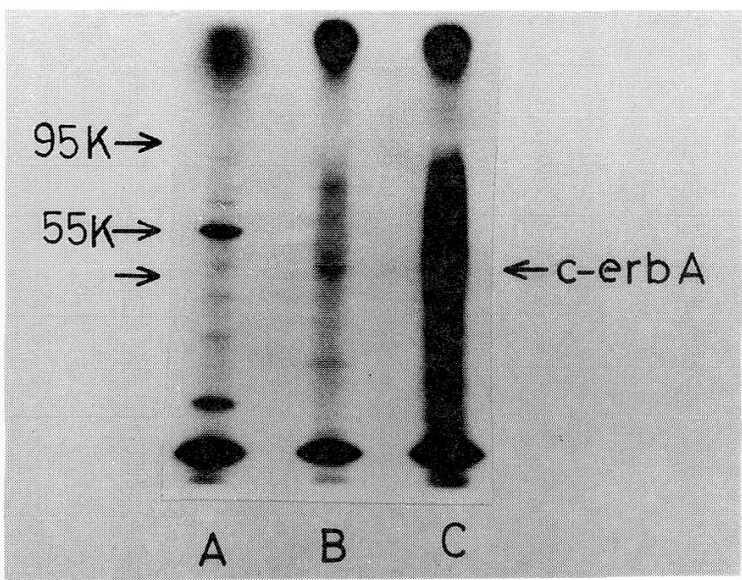

Fig. 4. Phosphorylation of $c$-erb $A$ protein in the presence of protein kinase III. A: Phosphorylation with P.K. III. B: Phosphorylation with P.K. III and precipitated with anti $c$-erb $A$ antibody. C: Phosphorylated with whole nuclear extract. Two-hundred $\mu \mathrm{g}$ protein $(200 \mu l)$ of solubilized $E$. coli which expressed c-erb $A$ was incubated with $1.25 \mu \mathrm{g}$ protein kinase III (lanes A and B) or with $105.0 \mu \mathrm{g}$ protein of whole nuclear extract (lane $\mathrm{C}$ ) in the presence of $\mathrm{r}\left[{ }^{32} \mathrm{P}\right] \mathrm{ATP}$ in a final volume of $250 \mu \mathrm{l}$. After incubation, $50 \mu l$ samples were applied to SDS-PAGE (lanes A and C). After incubation, to the material was added Laemmli's sample buffer and incubated as described, then the material was incubated with anti-c-erb $A$ antibody after passing through the column of Extracti-gel D. The c-erb A denatured by SDS was recovered by immunoprecipitation with the antibody, dissolved with $50 \mu$ l Laemmli's sample buffer and applied to SDSPAGE (lane B).

kinases, are able to stimulate phosphorylation of c-erb A protein. In addition to the cyclic AMPdependent kinase, 6.0s protein kinase which was not dependent on cyclic nucleotides stimulated phosphorylation of $c$-erb $A$ protein. The $K m$ value was lower in this kinase than in cyclic AMPdependent protein kinase in nuclei, suggesting that the 6.0 s kinase is one of the main kinases for $c$-erb A phosphorylation. When casein was used as a substrate for protein kinases, the 6.0s enzyme did not phosphorylate the substrate. In view of this finding, it was speculated that substrate specificity might be present in this enzyme. As demonstrated by Goldberg et al. [14], serine residues in c-erb $A$ protein were phosphorylated by stimulating cyclic AMP-dependent protein kinase or protein kinase $\mathrm{C}$, and one of these sites is located in the amino-terminal domain of the molecule. In our study, however, we could not determine the site of phosphorylation in c-erb $A$ protein since the

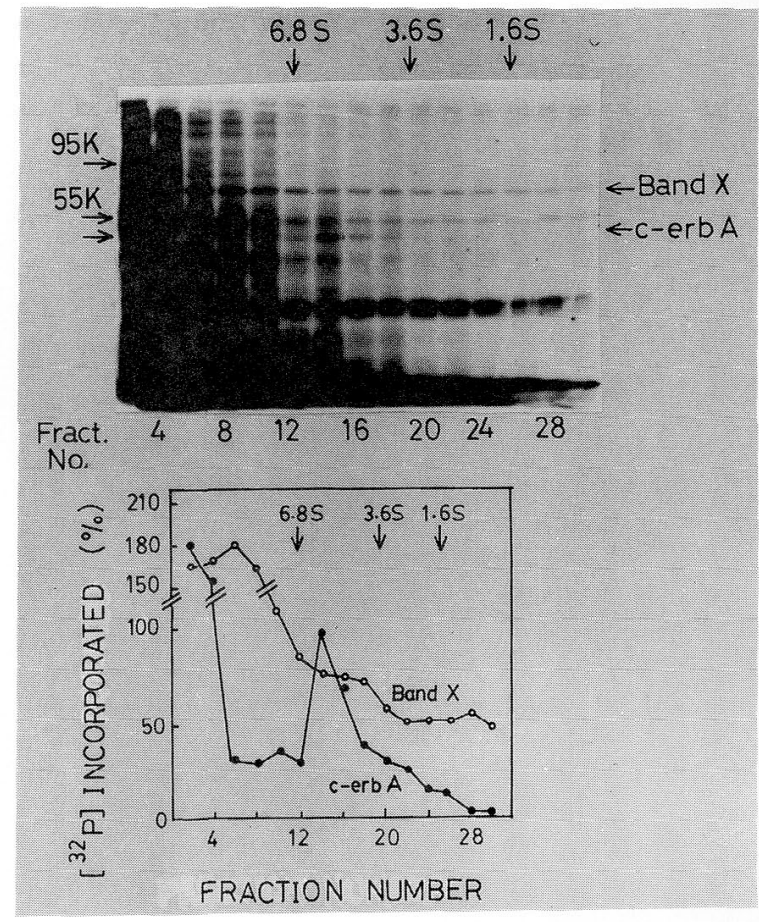

Fig. 5. Sucrose density gradient centrifugation of protein kinase III. One-hudnred $\mu l$ (30.0 $\mu \mathrm{g}$ protein) of protein kinase III-containing fraction was applied onto a $5-20 \%$ sucrose density gradient, and centrifugation was performed as described under "Materials and Methods". After fractionation, the $c$-erb A product-containing fraction (200 $\mu \mathrm{g}$ protein) was incubated with $50 \mu \mathrm{l}$ of aliquots in each fraction in a final volume of $150 \mu l$ with $\mathrm{r}\left[{ }^{32} \mathrm{P}\right] \mathrm{ATP}$. After the phosphorylation reaction, samples were applied to SDS-PAGE. The upper panel shows an autoradiography of the phosphorylated proteins. The lower panel shows radioactivity measured by means of the Cerenkov effect in each c-erb $A$ product or Band X excised from each lane. One-hundred percent was defined as the radioactivity incorporated into the c-erb $A$ protein band in lane 14. Positions of $6.8 \mathrm{~s}$ and $1.6 \mathrm{~s}$ marker proteins are also indicated.

amount of phosphorylated protein was not large enough to analyze the site of phosphorylation. We could detect the two nuclear protein kinases which phosphorylate c-erb A product. The results suggested that there might be several kinases which are distinct from these kinases.

During our studies, we observed that c-erb $A$ protein expressed in E. coli enhanced the phosphorylation of $55 \mathrm{kDa}$ protein which was one of the components of E. coli (Fig. 4). We could not characterize the precise mechanism of c-erb $A$ product-induced augmentation of phosphorylation. However, the fact that the enhancement was 


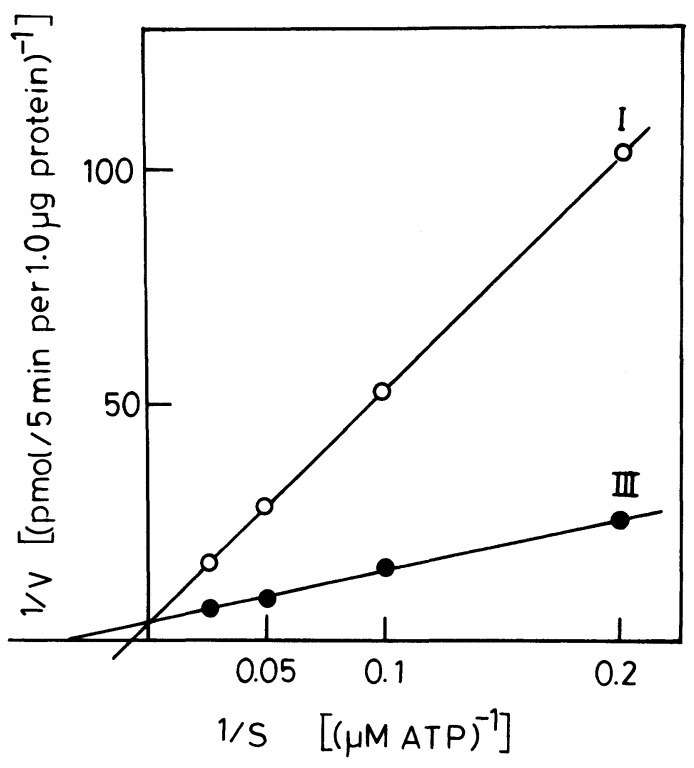

only observed in the presence of protein kinase III indicated that the c-erb $A$ product has the potency to activate the enzyme.

Analysis of stoichiometry of c-erb $A$ protein phosphorylation showed that it was low $(1: 80)$. The precise reason why the value was low could not be solved. A certain mechanism, such as the interaction of the enzyme with certain molecule(s), might be required to complete activation of the enzyme.

Steroid hormone receptors, whose structural and functional properties are closely related to
Fig. 6. Double-reciprocal analysis of phosphorylation of $c$-erb $A$ protein. A $c$-erb $A$ product-containing fraction $(200 \mu \mathrm{g}$ protein) was incubated with $15.0 \mu \mathrm{g}$ of protein kinase I $(\bigcirc)$ or III $(\bigcirc)$ with various concentrations of ATP $(0-40 \mu \mathrm{M})$ (including radioactive ATP). The activity of the protein kinase I was measured in the presence of $10^{-6} \mathrm{M}$ cyclic AMP. After the reaction, each sample was electrophoresed and the phosphate incorporated into $c$-erb $A$ protein was measured by means of Cerenkov effect of the protein band excised from the gel.

those of thyroid hormone receptors, were reported to be phosphorylated. Although the role of these phosphorylation events has not been thoroughly clarified, the phosphorylation appeared to correlate with the hormone-binding capacity of the receptor [12] or with hormone-induced transformation of the receptor to a high nuclear affinity state [13]. While the role of phosphorylation of $c$-erb $A$ protein by nuclear protein kinase is no doubt important, the action of the phosphorylated c-erb $A$ protein remains to be elucidated.

\section{References}

1. Jansson M, Philipson L, Vennstrom B (1983) Isolation and characterization of multiple human genes homologous to the oncogenes of avian erythroblastosis virus. The EMBO J 2: 561-565.

2. Weinberger C, Thompson CC, Ong ES, Lebo R, Gruol DJ, Evans RM (1986) The c-erb A gene encodes a thyroid hormone receptor. Nature 324: 641-646.

3. Thompson CC, Weinberger C, Lebo R, Evans RM (1987) Identification of a novel thyroid hormone receptor expressed in the mammalian central nervous system. Science 237: 1610-1614.

4. Benbrook D, Pfahl M (1987) A novel thyroid hormone receptor encoded by a cDNA clone from a human testis library. Science 238: 788-791.

5. Ichikawa K, Hashizume K, Furuta S, Osumi T, Miyamoto T, Yamauchi K, Takeda T, Yamada T (1990) Human c-erb A protein expression in Escher- ichia coli: changes in hydrophobicity upon thyroid hormone binding. Molecul Cellul Endocrinol 70: 175-184.

6. Flug F, Copp RP, Casanova J, Horowitz ZD, Janocko Plotnick LM, Samuels HH (1987) cisacting elements of the rat growth hormone gene which mediate basal and regulated expression by thyroid hormone. J Biol Chem 262: 6373-6382.

7. Ye ZS, Samuels HH (1987) Cell- and sequencespecific binding of nuclear proteins to 5'-flanking DNA of the rat growth hormone gene. $J$ Biol Chem 262: 6313-6317.

8. Koenig RJ, Brent GA, Warne RL, Larsen PR, Moore DD (1987) Thyroid hormone receptor binds to a site in the rat growth hormone promoter required for induction by thyroid hormone. Proc Natl Acad Sci USA 84: 5670-5674.

9. Glass CK, Franco R, Weinberger C, Albert VR, 
Evans RM, Rosenfeld MG (1987) A c-erb A binding site in rat growth hormone gene mediates transactivation by thyroid hormone. Nature 329: 738-741.

10. Weinberger C, Hollenberg SM, Rosenfeld MG, Evans RM (1985) Domain structure of human glucocorticoid receptor and its relationship to the v-erb A oncogene product. Nature 318: 670-672.

11. Green S, Walter P, Kumar V, Krust A, Bornert JM, Argos P, Chambon P (1986) Human oestrogen receptor cDNA: sequence, expression and homology to v-erb A. Nature 320: 134-139.

12. Migliaccio A, Rotondi A, Auricchio F (1984) Calmodulin-stimulated phosphorylation of 17estradiol receptor on tyrosine. Proc Natl Acad Sci USA 81: 5921-5925.

13. Logeat F, Le Cunff M, Pamphile R, Milgrom E (1985) The nuclear-bound form of the progesterone receptor is generated through a hormonedependent phosphorylation. Biochem Biophys Res Commun 131: 421-427.

14. Goldberg, Y, Glineur C, Fesquiere JC, Ricouart A, Sap J, Vennstrom B, Ghysdael J (1988) Activation of protein kinase $\mathrm{C}$ or cAMP-dependent protein kinases phosphorylation of the c-erb A-encoded thyroid hormone receptor and of the v-erb $A$ encoded protein. The EMBO J 7: 2425-2433.

15. Maniatis T, Fritsch E, Sambrook J (1982) Molecular Cloning, A Laboratory Manual. Cold Spring Harbor Laboratories, Cold Spring Harbor, New York.

16. Ichikawa K, Hashizume K, Takeda T, Kobayashi M, Suzuki S, Miyamoto T, Yamauchi K, Nishii Y, Yamada T (1989) Isoelectric point of nuclear thyroid hormone receptors. In: Lee M, Koh CS, Eastman CJ, Nagataki S (eds) Progress in Thyroidology 1989. Korea Medical Publishing Company, Seoul, Korea, pp 61-64.
17. Hashizume K, Miyamoto T, Ichikawa K, Yamauchi K, Kobayashi M, Sakurai A, Ohtsuka H, Nishii Y, Yamada T (1989) Purification and characterization of NADPH-dependent cytosolic 3,5,3'-triiodo-Lthyronine binding protein in rat kidney. $J$ Biol Chem 264: 4857-4863.

18. Hashizume K, Miyamoto T, Ichikawa K, Yamauchi K, Sakurai A, Ohtsuka H, Kobayashi M, Nishii Y, Yamada T (1989) Evidence for the presence of two active forms of cytosolic 3,5,3'-triiodo-L-thyronine ( $\mathrm{T}_{3}$ )-binding protein (CTBP) in rat kidney. Specialized functions of two CTBPs in intracellular $\mathrm{T}_{3}$ translocation. J Biol Chem 264: 4864-4871.

19. Ichikawa K, DeGroot LJ (1987) Purification and characterization of rat liver nuclear thyroid hormone receptors. Proc Natl Acad Sci USA 84: 3420-3424.

20. DeGroot LJ, Torresani J (1975) Triiodothyronine binding to isolated liver cell nuclei. Endocrinology 96: 357-364.

21. Hashizume K, DeGroot LJ (1979) Adenosine 3', 5'-monophosphate-dependent protein kinase activity in soluble thyrotropin receptor complex. Endocrinology 104: 1739-1745.

22. Laemmli UK (1970) Cleavage of structural proteins during assembly of the head of the bacteriophage T4. Nature 227: 680-685.

23. Lowry OH, Rosebrough NS, Farr AC, Randall RS (1951) Protein measurement with the Folin phenol reagent. J Biol Chem 193: 265-275.

24. Ichikawa K, Hashizume K, Furuta S, Nishii Y, Miyamoto T, Osumi T, Yamauchi K, Ohtsuka H, yamada T, DeGroot LJ (1988) Conformational transition of human c-erb $A$ protein upon thyroid hormone binding. In: Nagataki S, Torizuka K (eds) The Thyroid. Excerpta Medica, New York, pp 357-360 